\title{
Planning: A Tool for Administration of Teachers' Competence Development Programmes for Improved Service Delivery in Secondary Schools in Rivers State, Nigeria.
}

\author{
Dr. (Mrs) P. C. Ukaigwe \\ Department of Educational Management Faculty of Education, \\ University of Port Harcourt, Rivers State, Nigeria. \\ Innocent U. Igbozuruike \\ Department of Educational Management Faculty of Education, \\ University of Port Harcourt, Rivers State, Nigeria.
}

\begin{abstract}
The study examined the role of planning in the administration of Teachers Competence Development Programmes (TCDPs) for improved service delivery in secondary schools in Rivers State, Nigeria. The descriptive research design was adopted for the study. The population of the study consisted of 274 principals in public secondary schools in Rivers State. A sample size of 130 principals was drawn using proportionate random sampling technique. A validated questionnaire instrument titled "Principals' Decisionmaking and Interpersonal Skills for Effective Administration of Public Secondary Schools Questionnaire' (PDISEAPSSQ)" was used to generate data used in the study. The instrument has reliability index of 0.83 , using test retest test method. The research questions were analysed and answered using mean and mean-set, whereas the research hypotheses were tested using z-test statistics at 0.05 alpha level. The findings of the study showed that TCDPs helped to increase the competencies of teachers in the areas of teaching skills, communication skills and classroom management skills, lesson planning skills and enabling attributes. This study revealed that adequate planning of TCDPs ensures that selected programmes are goal directed and ensures that needs of learners are determined from the onset so that the objectives of TCDPs are tailored accordingly. The findings of the study also showed that proper planning of TCDPs ensures that the required resources for successful implementation of TCDPs plans are earmarked and set aside for the designated purposes. Recommendations made among others included that, educational planners and administrators who are responsible for TCDPs in the State Ministry of Education should design and integrate programmes that will address the deficiencies of teachers in subject-specific areas, and also make similar arrangements directed at educating teachers on how to use ICT facilities to research and teach easily.
\end{abstract}

Keywords: Planning, Administration, Teachers' Competence Development Programmes (TCDPs), Secondary Schools, Rivers State, Nigeria.

\section{INTRODUCTION}

The goal of all schools is to enable their students to excel. However, the school cannot achieve this if the teachers are not competent enough to impart the required knowledge and skills to succeed in life. Teachers are the pillars of quality education edifice. This is not because they play active roles in teaching and learning process only, but also because they perform the parental functions of caring, advising, protecting and teaching students life skills as required by the doctrine of in-loco parentis. Beyond these traditional functions, the role of teachers in the rapidly changing society have continued to increase alongside with the demand on schools to 
add value to their services so that graduates can measure up with their expectations in both labour market and in performance of social responsibilities. These expectations have broadened the tasks of teachers, particularly in areas of teaching largely heterogeneous students who came from different backgrounds and cultures. Apart from managing and assisting students with peculiar needs and involving parents in school's affairs, contemporary teachers are also required to learn how to use Information Communication Technologies (ICTs) in teaching and learning processes, students' assessments, records keeping and other documentations. Ikegusi and Modebelu (2016) observed that knowledge of how to use computer and its peripheries has in recent times become essential tools in the performance of educational tasks. Modern teachers are also expected to be competent in imparting higher order thinking skills in the students, particularly decisive skills such as creative thinking, analytical thinking, problem-solving and decision-making skills.

These suggest that teachers' duties are broad, dynamic and evolving so rapidly that the traditional teacher education programme, which only offers rudimentary knowledge of teaching and learning process to intending teachers, is narrow in scope and insufficient in equipping the today's teachers adequately for effective performance of their duties. In this regard, teachers need to expand their competencies; knowledge-base, teaching skills and teaching techniques through trainings and personal development efforts with a view to acquiring new knowledge and methods to leverage on innovations and new technologies designed to improve teaching and learning experiences and students' learning outcomes. Buttressing this point, Obaya (2014) in Ukaigwe and Adieme (2018:32) asserted that 'there is need to train teachers to improve their knowledge and professional effectiveness in order to replace dated pedagogical practices that still underpin the educational system in Nigeria secondary schools". In the same vein, Ukaigwe and Onwumere (2018) maintained that involvement of teachers in capacity-building programmes is one of the key ways of equipping them with essential teaching skills that aid maximum productivity and enhanced academic performance of students.

Concept of Competence: Competence in the context of this paper is the combination and use of knowledge, skills and attitudes to accomplish tasks effectively. Teacher's competence is the ability of a teacher to deploy acquired knowledge and professional expertise such as technical and communication skills, motivational and managerial skills, values, attitudes and personality traits necessary for arousing and sustaining learners' interest and involvement in teaching and learning for maximal comprehension and instructional outcomes on the part of students (Koster \& Dengerink, 2008). Rychen and Salganik (2003) as cited in Caena (2011) viewed teacher's competence as the ability of a teacher to leverage on acquired knowledge (subject, content, skills) and mastered motivational tactics in meeting instructional needs of students. These definitions suggests that competence involves explicit knowledge of specialty, teaching know-how and psychological facilities (i.e. enabling belief system, ethical codes, motivational strategies and dispositions) that support effective teaching and learning. Teacher's competence also involves complex cognitive operations that permits individual teacher to think and act quickly, adaptively and consistently in performing his or her duties. This implies that teachers need excellent subject knowledge, flexible dispositions and interpersonal skills for managing diversities among members of school community who came from different sociocultural and linguistic backgrounds (European Commission, 2013).

Admittedly, many teachers do not have pertinent skills such as digital skills, classroom management and administrative skills; especially newly recruited teachers and even some experienced ones in some instances (Okoro, 2013; Ebong, 2006). Oluwatayo, Adirika and Wodi (2014) argued that the influx of unqualified and incompetent personnel into teaching 
profession has not only contributed to poor teaching and learning outcomes, but has also brought considerable disrepute to teaching profession. By implication, many teachers need Competence Development Programmes (CDPs) to build their capacities.

Teachers Competence Development Programmes (TCDPs) are planned activities designed for increasing the capacities of teachers to perform their jobs satisfactorily. The programmes include seminars, conferences, symposium, orientation, mentoring, coaching, follow-up activities and so forth. Iroka (2016) remarked that TCDPs are essential vehicles with which schools transmit their philosophies and values into their employees. TCDPs creates platforms for teachers to connect, share scholarly ideas and exchange useful strategies that aid instructional delivery (Amadi \& Anaemeotu, 2013). Uche (2010) remarked that administrators should endeavour to organize TCDPs regularly in order to raise teachers' abilities to teach effectively.

The success of any teacher capacity building programme is dependent on the planning and administration of such programmes. Planning is conscious and deliberate effort of determining the future course of actions in advance, with a view to outlining programmes that will facilitate the attainment of desirable ends. Obasi (2012) stated that planning is deciding on aims to be attained, how to attain them and all the human and material resources required for realizing the predetermined aims. This involves systematic and rational processes of selecting from alternatives, the actions that will lead to the accomplishment of pre-set goals within the limit afforded by resource mix (Agabi, 1999). This involves defining programmes, networking the processes that will be involved, sequencing roles in most economical manner, and evaluating the procedural effectiveness and goals attainability prospects within the limits of available resources. In other words, the ultimate goal of planning is essentially to maximize benefits while optimizing available resources.

Teachers' competence development (TCD) planning is therefore a continuous process of identifying the pedagogical inefficiencies of teachers with a view to helping them to improve on their failings, by setting out programmes articulated to address the their weaknesses via capacity building programmes such as workshops, microteaching, mentoring, feedback, and follow-up and personal development activities focusing on increasing pedagogical expertise that have incremental function to students' learning outcomes. Accordingly, the role of the administrator in this regards is more of coordinating the network of activities associated with the programmes, by using available material and human resources rationally towards ensure that the planned programmes are executed as planned to produce the intended competencies in the teachers.

Planning TCDPs requires consensus among stakeholders in education about what constitute education presently; the role of the school and the teacher in education process and what learners ought to benefit from education. The definition of the roles and demarcation of functions of the various actors and constituent parts in education industry will provide clarification on what constitute teachers' competence and the aspect of competence that is lacking among the teachers. As soon as these roles are delineated alongside with short and long-term needs of the students, the team of planners and administrators will decide on what teachers should know and capable of doing to meet the learning needs of students. This will form the basis of what teachers should do and how to do it perfectly to maximize learning outcomes on the part of students. These processes require data gathering and analysis to determine the areas teachers need help and the specific teachers to receive more attention. The resulting information will equip educational planners and administrators to draft incisive data-based statements about expected learning outcomes on the part of students and learning 
needs on the part of teachers. The statements should define the categories of teachers that will participate in the TCDPs and state clearly and in measurable terms, the targeted competencies to cultivate or develop in teachers. This ought to be accompanied with appropriate programmes and activities tailored to achieve the set objectives, including follow-up arrangements and feedback mechanisms. More importantly, the objectives of the programmes and evaluation procedures under which plan implementation will be evaluated must be stated in advance. These objectives may include; improvements in teachers' performances marked by improvement in students' learning outcomes. Again, planning TCDPs without determining and considering the required resources to support the entire exercise, including follow-ups, interviews and feedback processes, may jeopardize plan implementation (Akpakwu, 2012).

The plan ought to incorporate support programmes that will help to reinforce continuous staff development and monitoring. Amadi and Anaemeotu (2013) remarked that adequate resources (i.e. time, funds and facilities) ought to be earmarked for any TCDPs because the availability of these resources will go a long way in ensuring the success of TCDPs.

There is considerable division among scholars over who should fund TCDPs. Caena (2011) stated that developing pedagogical and digital competences are professional tasks of the teacher. This argument seems to be grounded on the fact that a highly competent teacher who monetizes her services to earn personal gains is supposed to invest personally in her future income. On the contrary, Ikegusi and Modebelu (2016) contend that teachers' competence development is the responsibility of institutional leadership. In Nigeria, there are instances of school-based capacity-building initiatives, in which some secondary schools select one or a combination of TCDPs to strengthen the knowledge and skills of individual teachers in specific areas of their respective needs. Under this arrangement, the School-based Management Committee (SMC) synergies with the school principal and some experienced teachers in planning the selected programme and learning opportunities for the benefit of less-experience teachers. The learning opportunities or programmes could be seminar; refresher courses, microteaching, mentoring and supervision of less experienced teachers by more experience ones,

It is important to note that involving teachers in the planning phase of any sort TCDPs alongside with other stakeholders such as principals, parents, representatives of Ministry officials and other concerned parties contributes to its success. This will not only create platform for the teachers to express their challenges, expectations and make useful suggestions about what can be done to help them improve their competencies, but will also create a convergence in which meaningful deliberations could be initiated and learning gaps established. Because failure to align the TCDPs plans with the needs of teachers, relative to students' learning outcomes, will produce less or no result. Igbozuruike, Abinusawa and OkoliErnest (2017) reported that some teachers in public secondary schools in Rivers State were not committed to their work because of their nonchalant attitude to their duties. Walker (2014) corroborates this in her earlier study, where she observed that teachers in Nigeria are scarcely given training in their respective subjects, with the result that many of them lacked sound disciplinary knowledge and right skills to present a body of knowledge. Apart from that, teachers were also reported to have faced serious challenges in managing students' misbehaviours, associated stress and, poor remuneration, with the result that many of them are teaching with dissatisfaction about their job, and those who could not take the strain any more left teaching profession (Ofili, Usiholo \& Oronsaye, 2009).

Observations suggest that most secondary schools in Rivers State, particularly public school rarely engage in school-based TCDPs, apart from those sponsored by the state government. 
Walker (2014) further reported that most schools in Nigeria do not have functional TCDPs plan. She noted that few of the progressive private secondary schools who take advantage of TCDPs alongside with other staff welfare packages intended to encourage and retain competent teachers, are at the forefront of producing academically sound students with social and economic advantages.

\section{Statement of the Problem}

There is a consensus in literature that teachers' competency is a predictor of students' learning outcomes. This is perhaps why government regularly engage teachers in different forms of capacity building programmes. Preliminary observations suggested that there are existing programmes lined up for improving the competencies of teachers in secondary school system in Rivers State, however, the extent to which most of the programmes have been achieving the intended objectives seem largely unclear. This was discernable from the observable lack of digital skills and commitment among some teachers, which tend to reinforce the idea that TCDPs in the state may not have been producing the intended competencies in the teachers due to poor planning and implementation. Moreover, the instances of unprofessional conducts among teachers, which seem to have become a regular occurrence in secondary schools today, may be responsible for the poor achievements of students, of which TCDPs were originally designed to address. Thus, the researchers were constrained to examine how adequate planning can be used as a tool for improving the effectiveness of TCDPs implementation in secondary schools in Rivers State.

\section{Aim and Objectives}

The aim of this study was to investigate the role of planning in the administration of TCDPs for improved service delivery in secondary schools in Rivers State. Specifically, the study had the following objectives;

1. To find out the roles of planning in the administration Of Teacher's Competence Development Programmes (TCDPs) in senior secondary schools in Rivers State.

2. To find out the ways Teacher's Competence Development Programmes (TCDPs) have improved the competencies of teachers in senior secondary schools in Rivers State.

\section{Research Questions}

The following research questions were answered in the study.

1. What is the role of planning in the administration of teacher's competence development programmes (TCDPs) in senior secondary schools in Rivers State?

2. In what ways have teacher's competence development programmes (TCDPs) improved the competencies of teachers in senior secondary schools in Rivers State?

\section{Hypotheses}

The following hypotheses were tested in the study;

1. There is no significant difference between the mean ratings of male and female principals on the role of planning in the administration of TCDPs in senior secondary schools in Rivers State.

2. There is no significant difference between the mean ratings of male and female principals on the ways TCDPs have improved the competencies of teachers in senior secondary schools in Rivers State.

\section{METHODOLOGY}

The study adopted descriptive survey design. The population of the study consisted of 274 principals in public secondary schools in Rivers State, Nigeria. A sample size of 130 principals was drawn using proportionate random sampling technique. A validated questionnaire 
instrument titled 'Planning the Administration of Teachers' Competence Development Programmes in Secondary Schools Questionnaire (PATCPSSQ)' was used to generate data. The instrument was subjected to test retest reliability test, which yielded a co-efficient of 0.88 . The instrument's scale was a modified four points Likert's rating of Strongly Agree (SA), Agree (A), Disagree (D) and Strongly Disagree (SD). The instrument was validated by the researchers; it had two sections; Section A was designed to elicit bio-data of the respondents, while section B included 18 questionnaire items structured to obtain responses from the respondents. Data generated were analysed with the aid of SPSS version 22. Research questions were answered using, mean and aggregate mean-set. The criterion for acceptance was $x \geq 2.50$ whereas z-test statistics was used to test the hypotheses at 0.05 alpha level.

\section{RESULTS}

Research Question One: What is the role of planning in the administration of teacher's competence development programmes (TCDPs) in senior secondary schools in Rivers State?

Table 1: Mean and mean-set of male and female principals on the role of planning in the administration of teacher's competence development programmes (TCDPs) in senior secondary schools in Rivers State.

S/N Description of items

$\bar{x} \stackrel{\text { SD }}{\text { Male }}$\begin{tabular}{cccc}
\multicolumn{2}{c}{ Principals } & Mean- & Remarks \\
Female & SD & $\bar{x}-\bar{x}$ &
\end{tabular}

9 Adequate Planning of teachers' competence development programmes (TCDPs) ensures that proposed programmes are goal directed.

10 Planning ensures that measurable indicators are stated upfront and used for evaluating the efficacy of TCDPs plans.

11 Planning TCDPs helps to identify the learning needs of students, for which TCDPs are directed to address.

12 Planning TCDPs helps to determine the skills that teachers need to enhance learning among the students.

13 Proper planning of TCDPs ensures that selected programmes are articulated to address specific needs of teachers.

14 Planning TCDPs helps to ascertain the quantity and quality of human and material resources required to cultivate specific competencies in the teachers.

15 Proper planning of TCDPs eliminates waste and reduces cost incurred in organizing TCDPs.

16 Adequate planning of TCDPs integrates follow-up activities.

$\begin{array}{llllll}3.28 & 0.84 & 3.37 & 0.81 & 3.33 & \text { Agreed } \\ 3.35 & 0.87 & 3.28 & 0.77 & 3.32 & \text { Agreed } \\ 3.40 & 0.86 & 3.32 & 0.93 & 3.36 & \text { Agreed } \\ & & & & & \\ 3.21 & 0.94 & 3.19 & 0.88 & 3.20 & \text { Agreed } \\ 3.36 & 0.92 & 3.40 & 0.69 & 3.38 & \text { Agreed } \\ & & & & & \\ 3.29 & 0.87 & 3.31 & 0.84 & 3.30 & \text { Agreed } \\ 3.32 & 0.94 & 3.14 & 0.84 & 3.23 & \text { Agreed } \\ 2.80 & 0.88 & 2.95 & 0.96 & 2.88 & \text { Agreed } \\ 3.25 & \mathbf{0 . 8 9} & \mathbf{3 . 2 6} & \mathbf{0 . 8 4} & \mathbf{3 . 2 6} & \end{array}$

Aggregate

In table 2, the respondents agreed that all the itemized statements are roles of planning in the administration of TCDPs. The high aggregate mean-set of 3.26 indicates that the respondents opined strongly that planning plays indispensible role in administration and success of TCDPs.

Research Question Two: In what ways have teacher's competence development programmes (TCDPs) improved the competencies of teachers in senior secondary schools in Rivers State? 
Table 2: Mean and mean-set of male and female principals on the ways TCDPs have improved the competencies of teachers in senior secondary schools in Rivers State.

\begin{tabular}{cccccc}
\multicolumn{5}{c}{ Male } & \multicolumn{2}{c}{ Principals } & Females & $\begin{array}{c}\text { Mean- } \\
\text { set }\end{array}$ & Remarks \\
$\bar{X}$ & SD & $\bar{X}$ & SD & $\bar{X}-\overline{\times}$ & \\
& & & & & \\
3.27 & 0.81 & 3.38 & 0.67 & 3.33 & Agreed \\
& & & & & \\
2.43 & 0.97 & 2.52 & 0.80 & 2.48 & Disagreed \\
2.94 & 0.81 & 2.80 & 0.77 & 2.87 & Agreed \\
3.20 & 0.91 & 3.04 & 0.67 & 3.12 & Agreed \\
3.40 & 0.81 & 3.15 & 0.79 & 3.28 & Agreed \\
& & & & & \\
2.12 & 0.81 & 1.94 & 0.77 & 2.03 & Disagreed \\
3.24 & 0.72 & 3.07 & 0.63 & 3.16 & Agreed \\
2.74 & 0.67 & 2.88 & 0.71 & 2.81 & Agreed \\
$\mathbf{2 . 9 2}$ & $\mathbf{0 . 8 1}$ & $\mathbf{2 . 8 5}$ & $\mathbf{0 . 7 2}$ & $\mathbf{2 . 8 8}$ &
\end{tabular}

Table 1 above shows the degree to which the teachers benefited from TCDPs in Rivers State. The respondents agreed that teachers have benefited from TCDPs with respect to items 1, 3, 4, 5, 7 and 8, with mean-sets of 3.33, 2.87, 3.12, 3.28, 3.16 and 2.81. However, the respondents admitted that TCDPs had not helped teachers enough in acquiring more knowledge in their respective teaching-subjects and in ICT skills, as shown in items 2 and 6 with mean-sets of 2.48 and 2.03 respectively.

\section{Test of Hypotheses}

Ho1: There is no significant difference between the mean ratings of male and female principals on the role of planning in the administration of teacher's competence development programmes (TCDPs) in senior secondary schools in Rivers State.

Table 3: z-test analysis of the difference between the mean ratings of male and female principals on the role of planning in the administration of teacher's competence development programmes (TCDPs) in senior secondary schools in Rivers State.

\begin{tabular}{|c|c|c|c|c|c|c|c|c|c|}
\hline S/No & Respondents & $\mathbf{N}$ & Mean & SD & Df & $\begin{array}{l}\text { z- } \\
\text { cal. }\end{array}$ & z-crit. & $\begin{array}{l}\text { Sig. } \\
\text { Level }\end{array}$ & Remark \\
\hline 1. & Male & 82 & 3.25 & 0.89 & & & & & \\
\hline 2. & Female & 48 & 3.26 & 0.84 & 128 & 0.07 & \pm 1.96 & 0.05 & $\begin{array}{c}\text { Significant } \\
\left(\mathrm{H}_{\mathrm{o}} \text { accepted }\right)\end{array}$ \\
\hline
\end{tabular}

Table 4 shows that the calculated z-cal. of 0.07 is less than the z-critical of 1.96 at 128 degrees of freedom and 0.05 significance level, therefore the above null hypothesis is accepted.

$\mathbf{H o}_{2}$. There is no significant difference between the mean ratings of male and female principals on the ways TCDPs have the competencies of teachers in senior secondary schools in Rivers State. 
Table 4. z-test analysis of the difference between the mean ratings of male and female principals on the ways TCDPs have improved the competencies of teachers in senior secondary schools in

\begin{tabular}{|c|c|c|c|c|c|c|c|c|c|}
\hline \multicolumn{10}{|c|}{ Rivers State. } \\
\hline S/No & Respondents & $\mathbf{N}$ & Mean & SD & Df & $\begin{array}{l}\text { z- } \\
\text { cal. }\end{array}$ & z-crit. & $\begin{array}{l}\text { Sig. } \\
\text { Level }\end{array}$ & Remark \\
\hline 1. & Male & 82 & 2.92 & 0.81 & & & & & Not \\
\hline 2. & Female & 48 & 2.85 & 0.72 & 128 & 0.58 & \pm 1.96 & 0.05 & $\begin{array}{c}\text { Significant } \\
\left.\text { (Ho } \mathrm{H}_{\mathrm{o}} \text { accepted }\right)\end{array}$ \\
\hline
\end{tabular}

From table 3 , the calculated $\mathrm{z}$ value $(\mathrm{z}$-cal. $=0.58)$ is less than the $\mathrm{z}$-critical of 1.96 at 128 degrees of freedom and 0.05 significant level, hence the above null hypothesis is accepted .

\section{FINDINGS, DISCUSSION AND IMPLICATIONS}

The analysis of the data in table 1 showed that adequate planning of TCDPs ensures that selected programmes are goal directed, because planning ensures that learners' needs are determined from the onset and objectives of TCDPs established accordingly. This will enable planners to programme the activities in a manner that addresses the flaws of teachers and enrich their pedagogical skills. This study has also shown that proper planning of TCDPs ensures that the required resources for successful implementation of plan is earmarked and set aside; including time, money, human and material resources. This finding supports Akpakwu (2012) who observed that planning helps to set aside the resources with which TCDPs are successfully carried out, including, resources to cater for follow-up discussions and mentoring sessions, feedbacks and coaching activities. These findings are in agreement with Amadi and Anaemeotu (2013) who stated that proper planning of TCDPs is key to successful administration of the programmes; this is because effective planning of TCDPs ensures that the programmes are incisively designed to address learning needs of the teachers as they pertain to students learning needs.

These findings are also in accord with Ikegusi and Modebelu (2016) who observed that planning and administration of TCDPs helps to elevate the intellectual and professional abilities of teachers. It is therefore no wonder this study revealed that no significant difference existed between the mean-set of male and female principals on the role of planning in the administration of TCDPs in senior secondary schools in Rivers State. This suggests that the respondents were in accord that proper planning is central to successful administration of TCDPs. The importance of planning in making sure that TCDPs achieve their respective goals is inexhaustible because, it does not only aid to identify the learning needs of students, but also helps to pinpoint the weaknesses of teachers, upon which TCDPs are based and programmed to address.

The findings obtained from answering research question two showed that teacher's competence development programmes (TCDPs) helped teachers to improve their skills in teaching, communication, classroom management and lesson planning. In addition, TCDPs also helped the teachers to acquire more knowledge about their legal duties and new attitudes that supports teaching and learning. These findings are in agreement with Amadi and Anaemeotu (2013) who reported that in-service training improved teachers' competencies and greatly raised students' academic achievements. These findings are also in line with Iroka (2016) who reported that teachers' competencies were adequately managed in Abia State, with the result that teachers' competencies increased significantly, that students' learning outcomes improved markedly. Evidently, a well-planned staff development programme is an increasing function of students' academic performance and teachers successes in career. This is because, the more a teacher acquires more knowledge about how to do her job satisfactorily, the more the teacher 
improves in her job alongside with students' learning outcomes. Furthermore, the findings of this study showed that TCDPs had not addressed teachers' lapses in subject-knowledge and digital skills. These findings are consonant with the report of Walker (2014) who reported that TCDPs in most Nigeria schools are often organized with the omission of programmes that addresses the curriculum competencies of teachers. On the study conducted by Oluwatayo et al (2014), teachers were reportedly deficient in ICT skills. These could explain the reason why some teachers find it difficult to present new body of knowledge in their specialities (Walker, 2014). This study also revealed that no significant difference existed on the mean ratings of male and female teachers on the ways TCDPs have improved the competencies of teachers in senior secondary schools in Rivers State. This was because the respondents were united in their opinions. It is therefore of no wonder why Uche (2010) argued that school administrators should endeavour to subject their staff (teachers) to regular TCDPs so that they can acquire new knowledge and ways of doing their jobs better.

A Good knowledge of subject area is a vital requirement for effective teaching. Because a teacher must know adequately, what he wants to teach otherwise he will not perform satisfactorily. More importantly, the need for all teachers to acquire ICT skills remains a vital professional obligation. When a teacher has no ability to use ICT facilities such computers, smartphones and other audio-visual devices that have become indispensable in research and learning, the teacher's methods may be out-dated and her performance questionable. This is why the modern teacher is obliged to acquire the abilities to use digital facilities such as electronic boards and projectors to communicate. In this regard, planners and administrators of TCDPs should integrate programmes that cultivate ICT skills and broaden curriculum competencies of teachers in the TCDPs. This will go a long way in enriching the capacities of teachers to teach effectively.

\section{CONCLUSION}

Having established the ways TCDPs have increased teachers' competencies as well as being effective tools for raising the productivity of teachers, the importance of planning in ensuring their successes has been substantiated. This study therefore concludes that TCDPs helped to increase the competencies of teachers in the areas of teaching skills, communication skills and classroom management skills, lesson planning skills and enabling attributes. This study further concludes that adequate planning of TCDPs will enhance the effectiveness of the programmes and further strengthen the competencies of teachers and students achievements.

\section{RECOMMENDATIONS}

Based on the findings of the study, the following recommendations were made;

- Educational planners and administrators who are responsible for TCDPs in the State Ministry of Education should design and integrate programmes that will address the deficiencies of teachers in subject-specific areas. Similarly, arrangement should also be made with respect to educating teachers on how to use ICT facilities to research and teach.

- Educational planners and administrators should ensure that TCDPs are directed at solving identified teacher- related problems that stand in the way of effective teaching and learning.

- School principals should regularly engage teachers in a well-planned TCDPs so that their competencies will improve to match the expectations of today's teachers. 
Ukaigwe, P. C., \& Igbozuruike, I. U. (2019). Planning: A Tool for Administration of Teachers' Competence Development Programmes for Improved Service Delivery in Secondary Schools in Rivers State, Nigeria. Advances in Social Sciences Research Journal, 6(1) 91-100.

\section{References}

Akpakwu, S. O. (2012). Education Management: Theory and Practice. Makurdi Destiny VentHuber.

Amadi, E. C. \& Anaemeotu, P. (2013).Professional Development on Teachers' Academic Performance in Secondary Schools in Etche Local Government Area of River State, Nigeria. International Journal of Education Learning and Development,1(2), 19-23.

Caena, F. (2011). Education and Training 2020 Thematic Working Group Professional Development of Teachers: Literature review Teachers' core competences: requirements and development. Retrieved from http://ec.europa.eu/education/policy/strategic-framework/expertgroups_en\&sa=U\&ved=0ahUKEwjxuN2NrPbdAhWTOsAKHTLPC8QQFggQMAI\&usg=AOvVaw2UrM8MIYMfcWGpK $\underline{\text { ma_zFY8 }}$

Ebong, J. M. (2006). Understanding Economics of Education. Port Harcourt:Eagle Lithograph Press.

European Commission (2013). Supporting teacher competence development for better learning outcomes. Retrieved from https://www.google.com/url?q=http://ec.europa.eu/dgs/education_culture/repository/education/policy/school Ldoc/teachercomp_en.pdf

Igbozuruike, I. U., Abinusawa, D. N. \& Okoli-Ernest, C. O. (2017). Teachers' Productivity: A Strategy for Enhancing Quality Secondary Education in a Declining Economy of Imo State. African Journal of Educational Research and Development, 9(1) 126-137.

Ikegusi, N. G. \& Modebelu, M. N. (2016). Towards Training and Development Needs in Education. In M. N. Modebelu, O. L. Eya, J. Obunadike. Educational Management:The Nigeria Perspective. Akwa: SOCOA Heritage Nigeria Ltd.

Iroka, R. O. (2016). Managing Teachers' Competencies For Effective Teaching in Abia State Secondary Schools. Trends in Educational Studies. Institute of Education, University of Port Harcourt, 9(1) 42-49.

Koster, B. and Dengerink, J. J.(2008). Professional standards for teacher educators: how to deal with complexity, ownership and function. Experiences from the Netherlands. European Journal of Teacher Education, 31(2) 135149.

Ofili, A. N., Usiholo, E. A. \& Oronsaye, M. O. (2009). Psychological morbidity, job satisfaction and intentions to quit among teachers in private secondary schools in Edo-State, Nigeria. Annals of African Medicine, 8 (1) 32 - 37.

Okoro, J. (2013). Assessment of effective communication competencies possessed by university business education graduates for successful running of businesses in South-South Nigeria. Global Journal of Management and Business Research Administration and Management, 13 (8) 35-43

Oluwatayo, G. K., Adirika, B. N. \& Wodi, L. L. (2014). Competencies of Nigerian Graduate Teachers: The Insiders' Perspectives.Journal of Emerging Trends in Educational Research and Policy Studies, 5(4): 577-584

Rychen, D.S. \& Salganik, L.H. (2003). Key Competencies for a successful life and a well-functioning society. Göttingen: Hogrefe \& Huber

Ukaigwe, P. C. \& Adieme, F. G. (2018). Teacher's training needs for sustainable functional secondary education in Imo State, Nigeria. European Journal of Research and Reflection in Educational Services, 6(4); 31-42.

Ukaigwe, P. C. \& Onwumere, O.A. (2018). Perceived impact of teaching staff management in their task performance for student's productivity in secondary schools in Rivers State. East African Journal of Educational Research and Policy, 15: 1-14.

Walker, J. (2014). Partnership to strengthen innovation and practice in secondary education. The role of research in teacher training and development: Case studies from Nigeria. Catholic University of America: The Education Partnership (TEP) Centre Catholic University of America: The Education Partnership (TEP) Centre. 